\title{
Effect of modified atmosphere applied to minimally processed radicchio (Cichorium intybus L.) submitted to different sanitizing treatments
}

Giuliana de Moura PEREIRA ${ }^{1}$, Caroline Isabel KOTHE ${ }^{1}$, Camila Czieslak MACHADO ${ }^{1}$, Stefani Machado LOPES ${ }^{1}$, Simone Hickmann FLÔRES ${ }^{1}$, Alessandro de Oliveira RIOS ${ }^{1 *}$

\begin{abstract}
Stability of minimally processed radicchio (Cichorium intybus L.) was evaluated under modified atmosphere $\left(2 \% \mathrm{O}_{2}, 5 \% \mathrm{CO}_{2}\right.$, and $93 \% \mathrm{~N}_{2}$ ) on $3,5,7$ and 10 days of storage at $5^{\circ} \mathrm{C}$. The samples were hygienized in sodium hypochlorite or hydrogen peroxide solutions to identify the most effective sanitizing solution to remove microorganisms. Microbiological analysis was conducted to identify the presence of coliforms at $35^{\circ} \mathrm{C}$ and $45^{\circ} \mathrm{C}$, mesophilic microorganisms, and yeast and mold. Physicochemical analyses of mass loss, $\mathrm{pH}$, soluble solids, and total acidity were conducted. The color measurements were performed using a Portable Colorimeter model CR-400. The antioxidant activity was determined by 2,2-diphenyl-1-picrylhydrazyl and 2,2-azinobis-3-ethylbenzothiazoline-6-sulfonic methods. The sensory evaluation was carried out using a hedonic scale to test overall acceptance of the samples during storage. The sodium hypochlorite (150 mg. $\left.\mathrm{L}^{-1}\right)$ solution provided greater safety to the final product. The values of $\mathrm{pH}$ ranged from 6.17 to 6.25 , total acidity from 0.405 to $0.435 \%$, soluble solids from 0.5 to $0.6{ }^{\circ}$ Brix, mass loss from 1.7 to $7.2 \%$, and chlorophyll from 1.068 to $0.854 \mathrm{mg} / 100 \mathrm{~g}$. The antioxidant activity of radicchio did not show significant changes during the first 3 days of storage. The overall acceptance of the sample stored in the sealed package without modified atmosphere was $70 \%$, while the fresh sample was obtained $77 \%$ of approval. Although the samples packaged under modified atmosphere had a higher acceptance score, the samples in sealed packages had satisfactory results during the nine days of storage. The use of modified atmosphere, combined with cooling and good manufacturing practices, was sufficient to prolong the life of minimally processed radicchio, Folha Larga cultivar, for up to ten days of storage.
\end{abstract}

Keywords: technology; antioxidant activity; sensory analysis; conservation.

\section{Introduction}

A balanced diet is currently considered a constant concern of consumers in the routine for a healthy lifestyle and to control body weight. Consumers are changing their eating habits and becoming aware of the relationship between diet and disease prevention. American government agencies and organizations for health promotion recommend increasing vegetables consumption (Walley \& Buchanan, 2011). Fresh foods are considered more nutritious and tasty than processed food products. Pre-cooked vegetables, for example, have become increasingly popular items on convenience store shelves. Due to their sanitary quality and practicality, they are sold washed, peeled, cut, and packaged (Maistro, 2001).

Chicory (Cichorium intybus L.) is an important agricultural crop in Europe and Asia. This species is known for its high antiradical activity, polyphenol and flavonoid contents (Heimler et al., 2009; Dalar \& Konczaka, 2014). Many research papers have been published on the phytochemical composition and health properties of Cichorium intybus, including antidiabetic properties and antioxidant capacity (Carazzone et al., 2013; Morales et al., 2014).

In the Indian and South African the Cichorium intybus is used for its antihepatotoxic, antiulcerogenic, anti-cancer, and anti-inflammatory properties (Nandagopal \& Kumari, 2007; Street et al., 2013). Radicchio is also known for having a bitter taste caused by some compounds, and the most abundant ones are lactucin, 8-deoxylactucin lactucopicrin and their 11(beta), 13-dihydro derivatives. (Peters et al., 1996).

Minimally processed vegetables are products that maintain their attributes and quality similar to those of fresh products (Alzamora et al., 2000). The purposes of minimal processing are to maintain the produce fresh without losing its nutritional quality and to extend its shelf life to facilitate commercialization. The quality of vegetables is a combination of physiological and organoleptic properties and nutritional characteristics that determine consumer acceptability (Manolopoulou et al., 2010).

'Modified atmosphere packaging' is a technique applied to different packaging technologies to modify the composition of the internal atmosphere of a package to improve the shelf-life of food products and to slow product degradation (Robertson, 2003).

To store fresh vegetables under modified atmosphere, it is necessary to reduce $\mathrm{O}_{2}$ and increase $\mathrm{CO}_{2}$ concentration; the atmosphere inside the pacakage changes successively as a result of $\mathrm{O}_{2}$ absorption and $\mathrm{CO}_{2}$ release during produce respiration and the gas transfer through the package film (Gorny, 2001).

However, the package enables the consumer to evaluate the quality of the product by its pigmentation. Generally, color 
change is associated with senescence and can be considered a key attribute along with the texture to determine the edible quality of the leaves (Streit et al., 2005). In situations where modified atmosphere is associated with cooling, which is used to reduce microbial growth, undesirable chemical and physiological changes modify the appearance of the product (Pirovani, 1998). The food market provides new and interesting opportunities for producers of radicchio and other vegetables to apply technologies that can modify food products in order to provide benefits to the consumer health. However, further studies addressing the effects of modified atmosphere packaging on minimally processed vegetables are necessary.

The objective of this study was to identify the most effective sanitizing solution (sodium hypochlorite or hydrogen peroxide) to remove microorganisms and to evaluate the effect of modified atmosphere on minimally processed radicchio, Folha Larga cultivar, stored under refrigeration.

\section{Materials and methods}

\subsection{Material}

Radicchio (Folha Larga cultivar) samples were acquired from CEASA-RS (Central Supply Center, RS, Brazil). The samples were collected and processed on the same day. The leaves were pre-selected considering the absence of visible injuries and infections, color, and size uniformity.

\subsection{Minimal processing of the samples}

The selected leaves were washed with water and subsequent cooled by immersion in cold water $\left(5^{\circ} \mathrm{C}\right)$ to subtract vital heat. The radicchio samples were immersed in a $150 \mathrm{mg} . \mathrm{L}^{-1}$ sodium hypochlorite solution or hydrogen peroxide (4\%) for 5 minutes to surface disinfection. The leaves were centrifuged to remove excess water and stored in multilayer polyethylene-nylon film under modified atmosphere ( $2 \%$ oxygen, $5 \%$ carbon dioxide and $93 \%$ nitrogen). The modified atmospheres recommended by Gorny (2001) are $\mathrm{O}_{2}: 0.5-3.0 \%$ and $\mathrm{CO}_{2}: 5.0-10.0 \%$.

The modified atmosphere packaging of the samples was performed using a packaging machine, Fastvac (model TM 250, TecMaq, Sao Paulo - Brazil). The packages contained an average of $50 \mathrm{~g}$ radicchio and were maintained at the temperature of $5 \pm 1^{\circ} \mathrm{C}$ for 10 days in a germination camera (model TE-401, Tecnal, Piracicaba SP) under 12 hour-photoperiod (light/dark cycle) to mimic the type of storage used for minimally processed products in the local market. Samples of 3, 5, 7, and 9 days of cold storage were subjected to sensory analysis. The samples were analyzed in natura (fresh) and stored in different types of pacages: open packages, sealed packages without modified atmosphere, and sealed packages with modified atmosphere.

\subsection{Microbiological analyses}

The presence of coliforms at $35^{\circ} \mathrm{C}$ and $45^{\circ} \mathrm{C}$, mesophilic microorganisms, and yeast and mold was investigated. After storage, $25 \mathrm{~g}$ of radicchio leaves from each treatment were collected and aseptically transferred to flasks containing $225 \mathrm{~mL}$
$0.1 \%$ peptone water $\left(10^{-1}\right.$ dilution). Decimal serial dilutions were then prepared and inoculated into the different culture media according to the Normative Instruction $n^{\circ} 62$ (Brasil, 2003). The analyses were carried out in duplicate and were expressed as the number of colony forming units per gram of sample (CFU/g).

\subsection{Physicochemical analyzes}

\section{Measurement of soluble solids, $\mathrm{PH}$, and total acidity}

The leaves were triturated using an Ultra Turrax tissue grinder (IKA T25 digital) at the ratio of 1:5 (leaf: water) and filtered through Whatman filter paper to evaluate the $\mathrm{pH}$, soluble solids, and total acidity (Association of Official Analytical Chemistry, 1992). The measurements of $\mathrm{pH}$ were performed using a benchtop pHmeter (mark QUIMIS), and the soluble solids were measured using a digital refractometer (ATAGO PocketPAL-3).

\section{Mass loss}

The mass of the leaves was measured using a SemiAnalytical Shimadzu Balance (model AY220) to determine the progress of mass loss. The results were expressed as percentage, and were obtained by the difference between the initial mass and the final mass of each sample.

\section{Chlorophyll}

Chlorophyll was determined after the leaves were ground in the Ultra Turrax tissue grinder (IKA T25 digital). One gram of material containing $50 \mathrm{~mL}$ of acetone was submitted to extractions complete decolorization of the sample.

After filtration, the volume of the extract was completed to $200 \mathrm{~mL}$, and absorbance was determined using a spectrophotometer (Ultrospec 3100 pro) at the wavelength of $652 \mathrm{~nm}$. Chlorophyll concentrations were measured in $\mathrm{mg}$ per $100 \mathrm{~g}$ of leaves (Engel, 1991). The calculation (mg) of chlorophyll per $\mathrm{g}$ fresh weight of leaf tissue was based on the Equation 1 (Witham et al., 1971):

chlorophyll $=\frac{A_{652} \times 1000 \times(V \div 1000 \mathrm{~W})}{34.5}$

Where: $\mathrm{A}=$ absorbance at the wavelength specified; $\mathrm{V}=$ volume of the final chlorophyll-acetone extract; $\mathrm{W}=$ grams of fresh plant material.

Color

The color measurements were performed using a Portable Colorimeter (CR-400). The CIELAB measurements obtained, $\mathrm{L}^{*}$ (lightness) and the color coordinates $\mathrm{a}^{\star}$ (red-green component) and $\mathrm{b}^{\star}$ (yellow-blue component) were compared with the sample correlations: chlorophyll found in the samples of minimally processed radicchio packaged under modified atmosphere at different storage times (Minolta, 1998). 


\section{Antioxidant activity}

Antioxidant activity was measured using the 2.2-diphenyl1-picrylhydrazyl (DPPH) (Kuskoski et al., 2005) and the 2.2-azino-bis-3-ethylbenzothiazoline-6-sulfonic (ABTS) methods (Brand-Williams et al., 1995). The results obtained using the DPPH method were expressed as the concentration of antioxidant required to reduce the original amount of free radicals by $50 \%$ (EC50), and the values were expressed as $\mathrm{g}$ fruit/g DPPH. As for the ABTS method, the results were expressed as micromolar Trolox concentration/g fruit.

\subsection{Sensory analysis}

Using a 9-point hedonic scale (1 - dislike extremely to 9 - like extremely), the samples were rated by 40 randomly selected untrained panelists. Each taster received an evaluation form for each sample to score the following attributes: appearance, color, flavor, texture, and overall acceptability (Meilgaard et al., 2007). Samples stored for 3, 5, 7, and 9 days were used in this analysis. The control sample (untreated sample) was also analyzed on different days at the different storage times.

This research was approved by the Ethics Committee in Research of UFRGS (\# 19171), according to Resolution 466/12 of the National Council of Health.

\subsection{Statistical analysis}

The data were analyzed by ANOVA. Differences between means were tested with the Tukey-Kramer HSD test at 5\% significance level. All analyses were performed with Statistica 10.0 software (Statsoft, 2005).

\section{Results and discussion}

\subsection{Microbiological analysis}

Table 1 shows the results of the microbiological analysis.

The quantitative analysis performed for coliforms at $35^{\circ} \mathrm{C}$ indicated that the control sample, which was washed in running water only, showed values close to a $2.5 \times 10^{5} \mathrm{CFU} / \mathrm{g}$. Samples sanitized with sodium hypochlorite solution (150 mg. $\left.\mathrm{L}^{-1}\right)$ showed values close to $4.3 \times 10^{2} \mathrm{CFU} / \mathrm{g}$ on the fifth day of treatment and $1.4 \times 10^{2} \mathrm{CFU} / \mathrm{g}$ on the tenth day of the treatment, indicating a three-log reduction in the microbial load.

The samples sanitized with a solution of hydrogen peroxide (4\%) had values around $2.2 \times 10^{3} \mathrm{CFU} / \mathrm{g}$ on the fifth day (two- $\log$ reduction) and $2.3 \times 10^{2} \mathrm{CFU} / \mathrm{g}$ on the tenth day (three-log reduction) of the experiment.

These significant reductions indicate that both tested solutions, when used in combination with modified atmosphere technology, were effective in inhibiting the growth of the microorganisms evaluated; however, the solution of sodium hypochlorite showed better results. There was a significant difference between the initial control sample and the sanitized samples on the fifth and tenth days of storage of the radicchio samples.

According to the results of the quantitative analysis, the presence of coliforms at $45^{\circ} \mathrm{C}$ was not detected during the entire storage period in the control sample, the samples sanitized with sodium hypochlorite solution (150 mg. $\left.\mathrm{L}^{-1}\right)$, and the samples sanitized with hydrogen peroxide solution $(4 \%)$. This result indicates appropriate post-harvest handling of the samples ensuring the safety of the vegetables during minimal processing.

The quantification of mesophilic microorganisms present in the radicchio samples was performed by standard counting. The analysis of the control sample showed values close to $9.8 \times 10^{7} \mathrm{CFU} / \mathrm{g}$. The samples sanitized with sodium hypochlorite solution (150 mg. $\mathrm{L}^{-1}$ ) showed values close to $5.1 \times 10^{2} \mathrm{UFC} / \mathrm{g}$ on the fifth day and $1.7 \times 10^{2} \mathrm{CFU} / \mathrm{g}$ on the tenth day of treatment. This result indicates that there was a five-log reduction in the microbial load, both during and at the end of storage period, when this sanitizing solution and modified atmosphere technology were used.

Samples sanitized with hydrogen peroxide (4\%) solution showed values close to $1.1 \times 10^{3} \mathrm{CFU} / \mathrm{g}$ on the fifth day and $3.0 \times 10^{2} \mathrm{CFU} / \mathrm{g}$ on the tenth day of the treatment. These results demonstrate a four-log reduction until the fifth day of storage, and a five-log reduction in the initial microbial load on the tenth day.

Both solutions tested were effective in inhibiting the growth of the microorganisms evaluated, but the sodium hypochlorite solution had the best results.

Values similar to those found in this study were reported by Babic \& Watada (1996) in a study on minimally processed spinach, in which the initial load of mesophilic microorganisms ranged between $10^{7}-10^{8} \mathrm{CFU} / \mathrm{g}$. Roversi \& Masson (2004) studied minimally processed lettuce packaged under modified atmosphere $\left(5 \% \mathrm{O}_{2}, 10 \% \mathrm{CO}_{2}\right.$, and $\left.85 \% \mathrm{~N}_{2}\right)$ and found the value of $1.55 \times 10^{8} \mathrm{CFU} / \mathrm{g}$ for the total count of bacteria on the tenth day of storage. This result differs from those obtained in the present

Table 1. Results of the microbiological analysis of coliforms at $35^{\circ} \mathrm{C}$ and $45^{\circ} \mathrm{C}$, mesophilic microorganisms, and yeast and mold in minimally processed radicchio (Cichorium intybus L.) submitted to different sanitizing treatments.

\begin{tabular}{|c|c|c|c|c|c|}
\hline Microbiological Analysis & Control & $\begin{array}{l}\text { Sodium hypochlorite } \\
\text { solution }\left(150 \mathrm{mg} \cdot \mathrm{L}^{-1}\right) \\
5 \text { days of storage }\end{array}$ & $\begin{array}{c}\text { Sodium hypochlorite } \\
\text { solution }\left(150 \mathrm{mg} \cdot \mathrm{L}^{-1}\right) \\
10 \text { days of storage }\end{array}$ & $\begin{array}{c}\text { Hydrogen peroxide } \\
\text { solution (4\%) } 5 \text { days } \\
\text { of storage }\end{array}$ & $\begin{array}{c}\text { Hydrogen peroxide } \\
\text { solution ( } 4 \% \text { ) } 10 \text { days } \\
\text { of storage }\end{array}$ \\
\hline Coliforms at $35^{\circ} \mathrm{C}(\mathrm{CFU} / \mathrm{g})$ & $2.5 \times 10^{5 a}$ & $4.3 \times 10^{2 \mathrm{~b}}$ & $1.4 \times 10^{2 b}$ & $2.2 \times 10^{3 \mathrm{~b}}$ & $2.3 \times 10^{2 b}$ \\
\hline Coliforms at $45^{\circ} \mathrm{C}(\mathrm{CFU} / \mathrm{g})$ & Absent & Absent & Absent & Absent & Absent \\
\hline Mesophilic microorganisms (CFU/g) & $9.8 \times 10^{7 \mathrm{a}}$ & $5.1 \times 10^{2 b}$ & $1.7 \times 10^{2 b}$ & $1.1 \times 10^{3 \mathrm{~b}}$ & $3.0 \times 10^{2 b}$ \\
\hline Yeast and mold (CFU/g) & $4.0 \times 10^{2 \mathrm{a}}$ & $1.5 \times 10^{1 \mathrm{~b}}$ & $0.5 \times 10^{1 b}$ & $3.0 \times 10^{1 \mathrm{~b}}$ & $0.8 \times 10^{1 b}$ \\
\hline
\end{tabular}

Means with the same letter in the same row indicates no significant difference at $5 \%$ level of significance. 
study, probably due to the fact that different plant genus were evaluated and to the pre- and post-harvest conditions.

Since fungus can grow and contaminate foods under conditions of low $\mathrm{pH}$ conditions and low refrigeration temperature, a quantitative analysis was carried out to detect the presence of yeast and mold in the radicchio samples. The results indicate that the control sample showed values close to $4.0 \times 10^{2} \mathrm{CFU} / \mathrm{g}$. Samples sanitized with sodium hypochlorite solution (150 mg. $\mathrm{L}^{-1}$ ) showed values close to $1.5 \times 10^{1} \mathrm{CFU} / \mathrm{g}$ on the fifth day of treatment and $0.5 \times 10^{1} \mathrm{CFU} / \mathrm{g}$ on the tenth day of treatment. Thus, there was a logarithmic cycle reduction in microbial population during storage.

The other samples sanitized with a hydrogen peroxide (4\%) solution had values close to $3.0 \times 10^{1} \mathrm{CFU} / \mathrm{g}$ on the fifth day and $0.8 \times 10^{1} \mathrm{CFU} / \mathrm{g}$ on the tenth day of treatment, similar to the results found for the hypochlorite solution. The low values of yeasts and molds show good hygiene and appropriate handling during processing. The centrifugation of the radicchio leaves also contributed to the reduction in humidity levels inside the package by inhibiting the growth of these types of microorganisms.
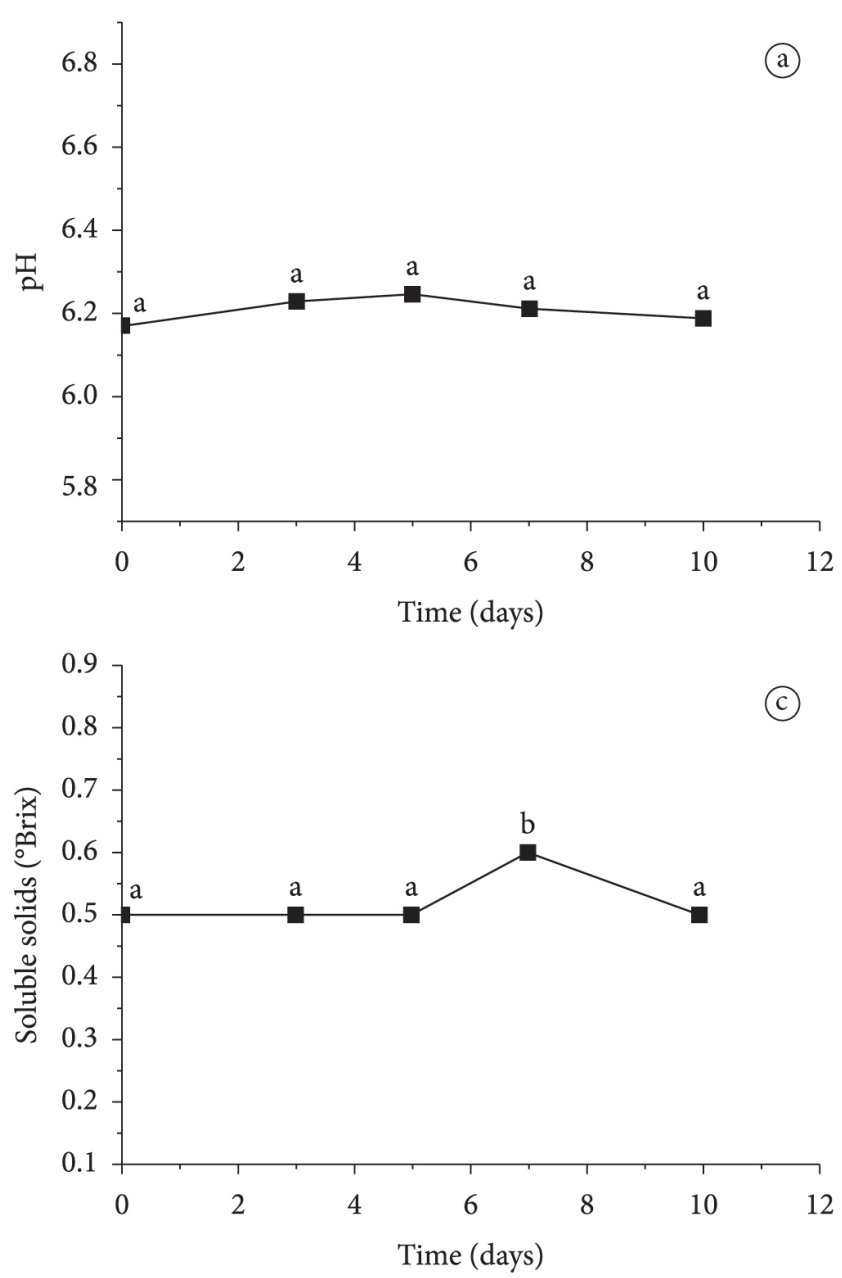

The levels of yeast in minimally processed spinach was considered low by Babic \& Watada (1996); they remained between $10^{3}-10^{4} \mathrm{CFU} / \mathrm{g}$ during nine days of storage, both in the surrounding air and under controlled atmosphere at $5^{\circ} \mathrm{C}$ and $10^{\circ} \mathrm{C}$.

Berbari et al. (2001) investigated the effect of chlorine on the wash water used to disinfect minimally processed lettuce and detected initial contamination of molds and yeasts with counts of $10^{4} \mathrm{CFU} / \mathrm{g}$. After nine days of storage, the samples were sanitized with a solution of $130 \mathrm{mg} / \mathrm{L}$ of chlorine and the load was estimated at $3.1 \times 10^{3} \mathrm{CFU} / \mathrm{g}$.

The results presented by the authors mentioned above are similar to those found in the present study, both in terms of the estimated level of molds and yeasts in the control sample and those detected in the sanitized samples at the end of the treatments.

Based on the fact that sodium hypochlorite was more effective than hydrogen peroxide in reducing microorganisms, in subsequent analyses, the samples were sanitized only with this sanitizing solution.
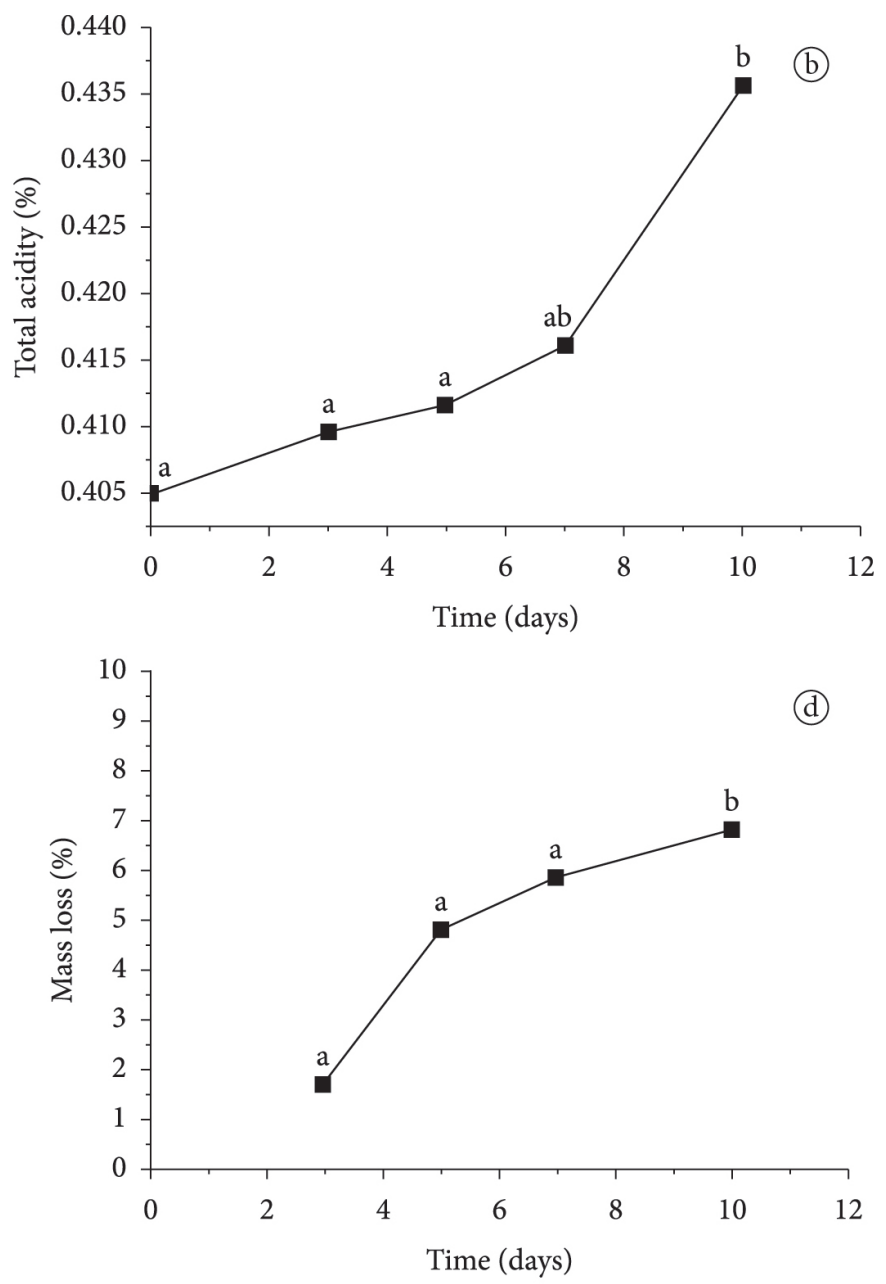

Figure 1. pH (a); soluble solids (b); total acidity (c); mass loss (d) of minimally processed radicchio cv., Folha Larga cultivar, packaged and stored under modified atmosphere at $5 \pm 1^{\circ} \mathrm{C}$ for a time period of 10 days. ${ }^{*}$ Different letters indicate significant difference according to Tukey test at $5 \%$ of probability. 


\subsection{Physicochemical analysis}

The $\mathrm{pH}$ values of the radicchio samples ranged from 6.17 to 6.25 (Figure 1a), and the storage time did not cause significant changes in this parameter. The $\mathrm{pH}$ of minimally processed vegetables is, in general, ranges from 5.8 to 6.5 . It has been found that the decrease in this variable can result in physiological disorders and deterioration of membranes (Ahvenainen, 1996).

Rinaldi et al. (2009) evaluated the stability of minimally processed cabbage in different packaging systems and found $\mathrm{pH}$ values ranging between 5.44 and 6.52 during 16 days of storage. Bolin \& Huxsoll (1991) analyzed the behavior of minimally processed lettuce $\mathrm{cv}$. Iceberg stored in plastic bags at $2^{\circ} \mathrm{C}$ and found the $\mathrm{pH}$ value of 6.03 .

The values of total acidity varied from 0.405 to $0.435 \%$ (Figure $1 \mathrm{~b}$ ), indicating an increase during storage under modified atmosphere.

Storage time did not cause significant changes in the acidity values until the seventh day. However, on the tenth day, the sample $(0.435 \%)$ showed a significant increase compared with the samples in the beginning $(0.405 \%)$ and on the third day $(0.409 \%)$ and fifth days $(0.412 \%)$ of the treatment. Bolin \& Huxsoll (1991) analyzed the behavior of minimally processed lettuce $\mathrm{cv}$. Iceberg, stored for 21 days, and found acidity values close to $0.50 \%$. Total acidity values remained stable, and no significant differences between the samples were detected during the storage period.

The values of soluble solids estimated for the radicchio samples during the 10 days of storage ranged from 0.5 to 0.6 ${ }^{\circ}$ Brix (Figure 1c). Storage time caused a significant change in this variable in the samples analyzed after seven days of storage under modified atmosphere $\left(0.6^{\circ} \mathrm{Brix}\right)$. This result may be associated with the radicchio post-harvest respiratory process.

Since photosynthesis stops and the modified atmosphere reduces respiration, the soluble solids content decrease because the respiration process consumes glucose.

Rinaldi et al. (2009) analyzed the stability of minimally processed cabbage in different packaging systems and found values of soluble solids ranging from 3.25 to $4.25^{\circ}$ Brix during 16 days of storage.

The mass loss values of the radicchio samples ranged approximately from 1.7 to $7.2 \%$ (Figure 1d) during the whole storage period under modified atmosphere.

The only significant difference in mass loss, compared with the other samples, was observed on the tenth day of storage.

Rinaldi et al. (2009) investigated the stability of minimally processed cabbage in different packaging systems and did not detect significant reduction in the mass loss, which maintained the maximum value of $0.46 \%$ for 16 days of storage. This result differs from that found in the present study indicating that it is important to determine the physiological behavior of each plant genus investigated.

The chlorophyll values found in the radicchio samples ranged from 1.068 to $0.854 \mathrm{mg} / 100 \mathrm{~g}$ (Figure 2a). Chlorophyll reduction was observed during storage. Storage time caused significant changes in the chlorophyll content of the radicchio samples, which could be observed on the seventh day $(0.871 \mathrm{mg} / 100 \mathrm{~g})$. Chlorophyll degradation was estimated at approximately $20 \%$ during the 10 days of storage.

Silva et al. (2007) studied methods to determine chlorophyll concentration in minimally processed lettuce and chives. Chlorophyll concentration, evaluated by spectrophotometry, reduced between the first day and seventh day of treatment, from 1.3 to $1.0 \mathrm{mg} / 100 \mathrm{~g}$, respectively, for lettuce and from $1.65 \mathrm{mg}$ to $1.5 \mathrm{mg} / 100 \mathrm{~g}$, respectively, for chives. These authors observed a chlorophyll reduction and degradation of approximately $23 \%$ for lettuce and $9 \%$ for chives. The radicchio samples showed low degradation of chlorophyll, when compared with that of other studies.

The values of $\mathrm{L}^{*}$ (brightness) ranged between 52.75 and 59.15; higher values indicate the preservation of the pigments or chlorophyll. Chlorophyll analysis and the increase in the variable $\mathrm{L}^{\star}$ during the storage period indicate that the storage time caused a significant difference in these values between the control (52.75) and the other samples evaluated (Figure 2b) until the seventh day of storage. This result showed a reduction in chlorophyll content in the radicchio leaves, resulting in lighter colored samples at the end of the experiment and the consequent increase in its brightness.

The values of the chromatic coordinate $\mathrm{a}^{\star}$ ranged from -23.53 and -21.80 (Figure 2c). This parameter is related to the red-green component of the chromaticity diagram, i.e., positive values indicate a red sample, and negative values indicate a greenish sample. The negative results obtained for this coordinate are expected for this variable. Coordinate $\mathrm{a}^{\star}$ values did not vary significantly during the ten days of storage and were not considered statistically significant in terms of storage time.

The values of the chromatic coordinate $b^{\star}$ ranged between 35.02 and 45.58 (Figure 2d). This parameter is related to the yellow-blue component of the chromaticity diagram, i.e., positive values indicate a yellowish sample, and negative values indicate a blue sample. The positive results obtained for this coordinate are expected for this variable.

The yellowing of the radicchio leaves is due to the deterioration on account of the chlorophyll degradation and concomitant production of carotenoids, which was masked by the presence of chlorophyll.

These biochemical changes are indicative of senescence of plants. Such color changes from green to yellow begin just after harvesting, but can be minimized by appropriate packaging, modified atmosphere, and refrigerated storage. There were no significant changes in the variable $b^{*}$ in terms of storage time during the experiment.

The influence of two storage temperatures $\left(0^{\circ} \mathrm{C}\right.$ and $\left.5^{\circ} \mathrm{C}\right)$ and three different packaging films (low density polyethylene of $60 \mathrm{~mm}$ thickness, medium density polyethylene of $60 \mathrm{~mm}$ thickness, and polyvinyl chloride) on lettuce were studied by Manolopoulou et al. (2009). The results showed that all types of packaging reduced mass loss in fresh-cut lettuces under cold 

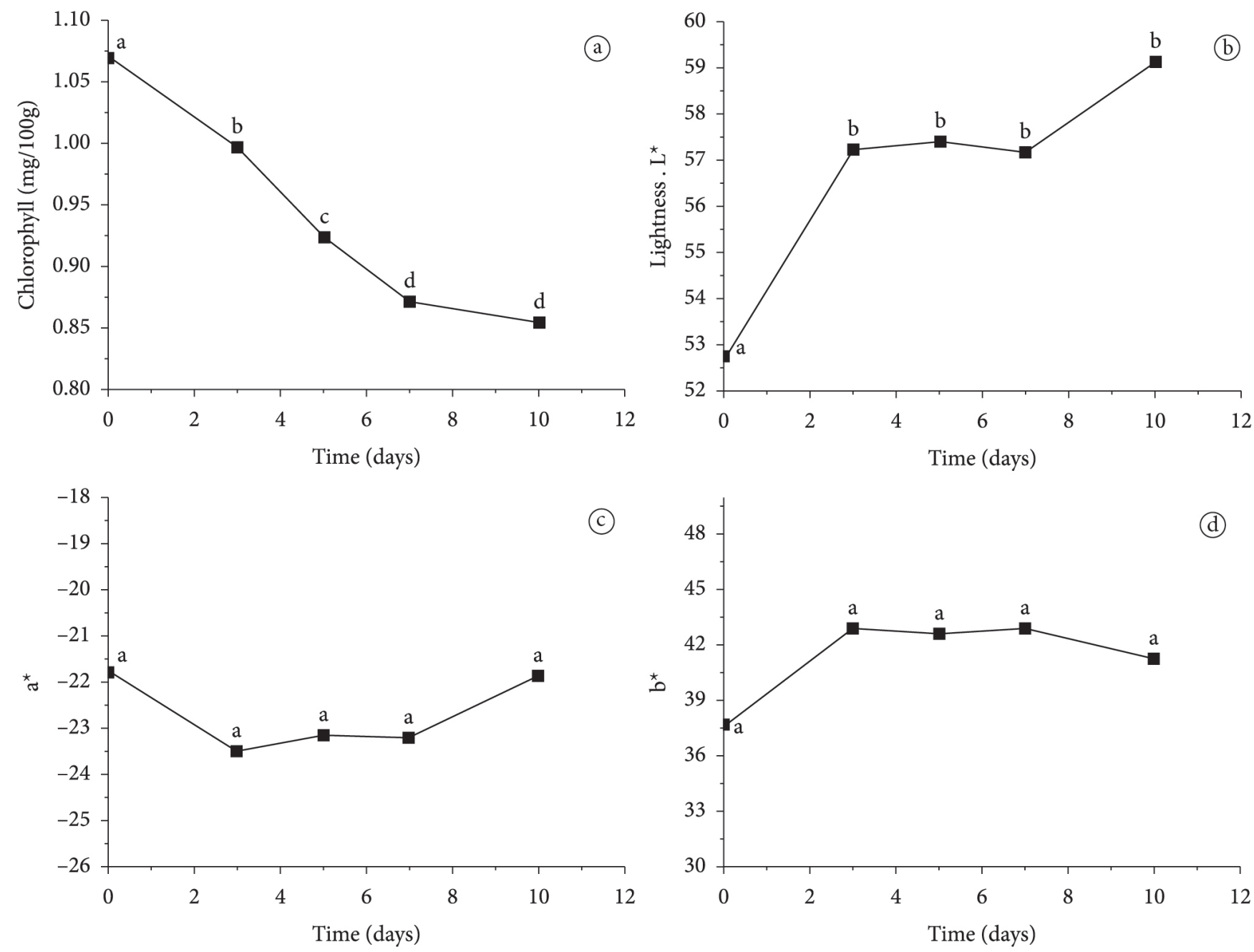

Figure 2. Chlorophyll (a); lightness $\mathrm{L}^{\star}(\mathrm{b})$; red-green component $\mathrm{a}^{*}(\mathrm{c})$; yellow-blue component $\mathrm{b}^{\star}(\mathrm{d})$ in minimally processed radicchio cv., Folha Larga cultivar, packaged and stored under modified atmosphere at $5 \pm 1^{\circ} \mathrm{C}$ for a period of 10 days. ${ }^{*}$ Different letters indicate significant difference according to Tukey test at $5 \%$ probability.

storage. Polyethylene film and the final storage time were the most significant factors affecting the color parameter evaluation. The modified atmosphere packaging of fresh-cut "Romaine" lettuce stored at low storage temperatures is highly suggested to avoid quality degradation.

The antioxidant activity of the radicchio samples (Figure 3) did not change significantly during the first 3 days of storage using the DPPH and ABTS methods, with average values of $1072.14 \mathrm{~g}$ radicchio/g DPPH and $7.72 \mathrm{mM}$ of trolox/g radicchio. On the fifth day of storage, there was an increase in the antioxidant activity according to these two methods, 650.61 $\mathrm{g}$ radicchio/g DPPH and $15.69 \mathrm{mM}$ of trolox/g radicchio. The antioxidant activity analyzed by DPPH showed no significant difference between the fifth and seventh day of storage, with a mean value of $703.46 \mathrm{~g}$ radicchio/g DPPH; however, the ABTS method showed a decrease to $6.76 \mathrm{mM}$ of trolox/g radicchio. After ten days of storage, there was a decrease in the antioxidant activity using the DPPH assay, $953.3 \mathrm{~g}$ radicchio/g DPPH, and

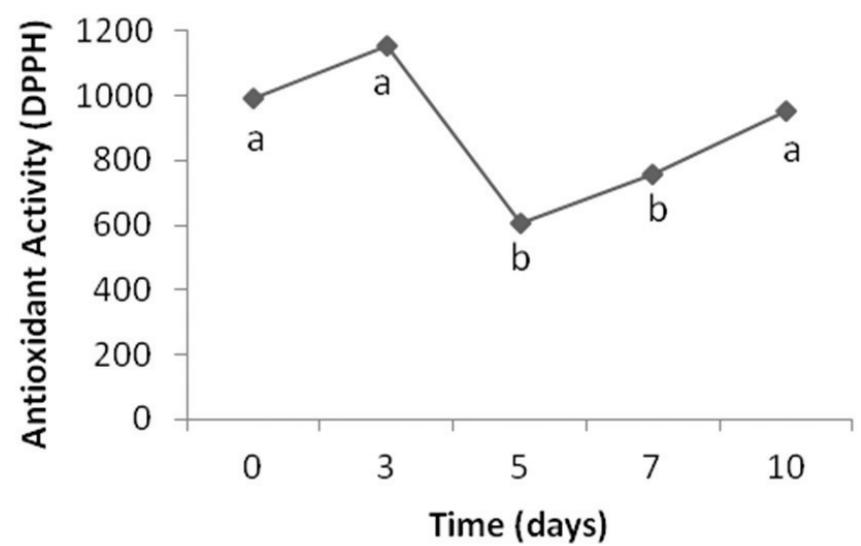

Figure 3. Antioxidant Activity using the ABTS method (a); Antioxidant Activity using the DPPH method (b) in minimally processed radicchio cv., Folha Larga cultivar, packaged and stored under modified atmosphere at $5 \pm 1^{\circ} \mathrm{C}$ for a period of 10 days. ${ }^{\star}$ Different letters indicate significant difference according to Tukey test, at $5 \%$ of probability. 
an increase using the ABTS method, $10.94 \mathrm{mM}$ of trolox/g radicchio, which is close to the value obtained in the first analysis without storage (day 0).

The total antioxidant capacity of vegetables depends on several compounds, such as flavonoids, phenolic acids, amino acids, ascorbic acid, tocopherols and pigments, and interactions between these groups. According to Chu et al. (2000), it is not easy to understand the causes of antioxidant activity variation in vegetables during storage; however, a similar variation was found in minimally processed celery stored at $4^{\circ} \mathrm{C}$.

Cichorium intybus var. Silvestre and Cichorium intybus var. Foliosum have been investigated for their antioxidant activity. The lipid peroxidation assay has been carried out on microsomal membranes of rat hepatocytes after the induction of oxidative damage by carbon tetrachloride, and the antiradical activity was expressed as the protective activity against lipid peroxidation (Gazzani, et al., 2000).

Cichorium intybus L., cv. Spadona was cultivated under biodynamic and conventional production systems. In the first analysis, there were no differences in the antiradical activity, while in the second analysis, the antiradical activity was higher under biodynamic conditions (Heimler et al., 2009).
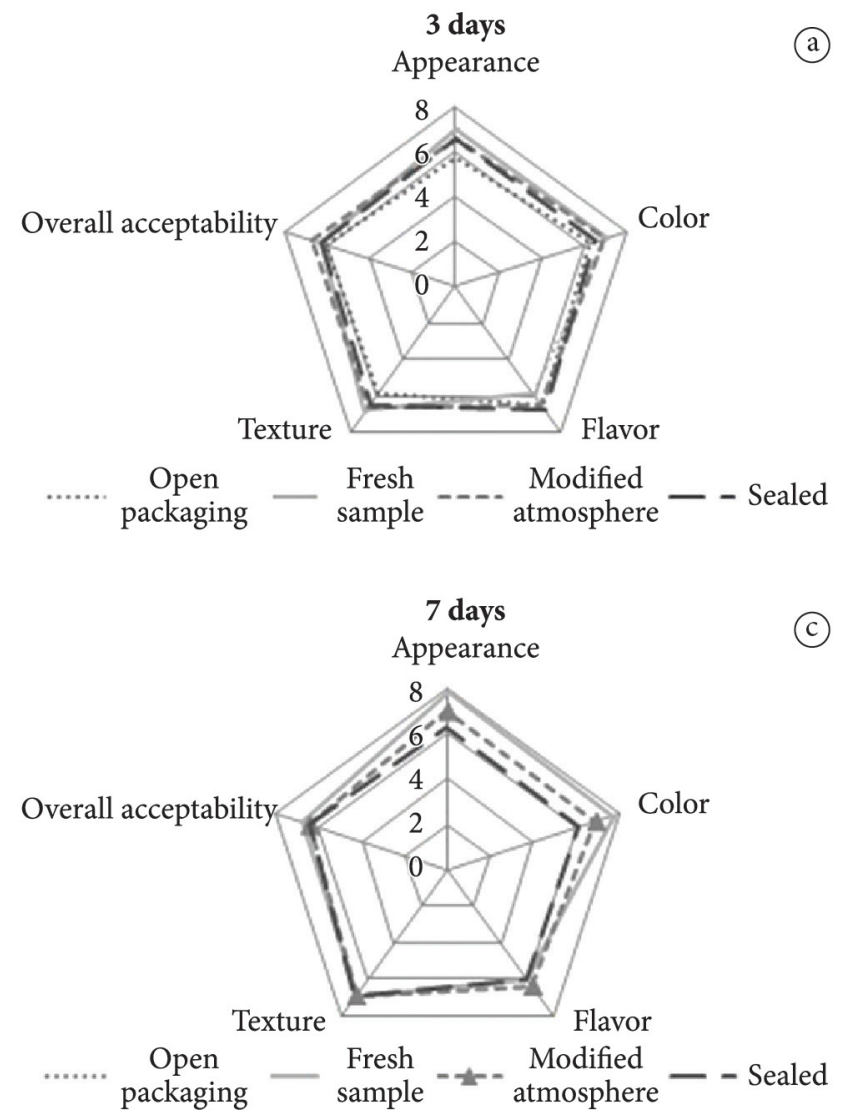

\subsection{Sensory analysis}

Sensory evaluation indicates that the use of modified atmosphere enables the conservation of the sensory attributes for up to 3 days of storage.

The overall acceptability of fresh unpackaged samples, sealed, and packaged under modified atmosphere and stored for 3 days, was around $72 \%$ and the overall acceptability of open sample was scored 67\% (Figure 4a).

On the fifth day of storage, there was a significant difference in the unpackaged radicchio samples, except for the flavor attribute, for which there was no significant differences between the samples (Figure 4b). The overall acceptability of unpackaged, sealed, and samples packaged under modified atmosphere for 5 days was around 70\%. As can be seen in Figure 4, the unpackaged sample obtained lower score of overall acceptance, reaching $52 \%$.

The unpackaged samples deteriorated after seven days of storage and could not be used in the acceptance test anymore. Furthermore, there was a difference in the appearance and color of the radicchio samples in the sealed packages (Figure 4c). As for color, the fresh unpackaged samples did not exhibit any significant difference when compared with samples packaged
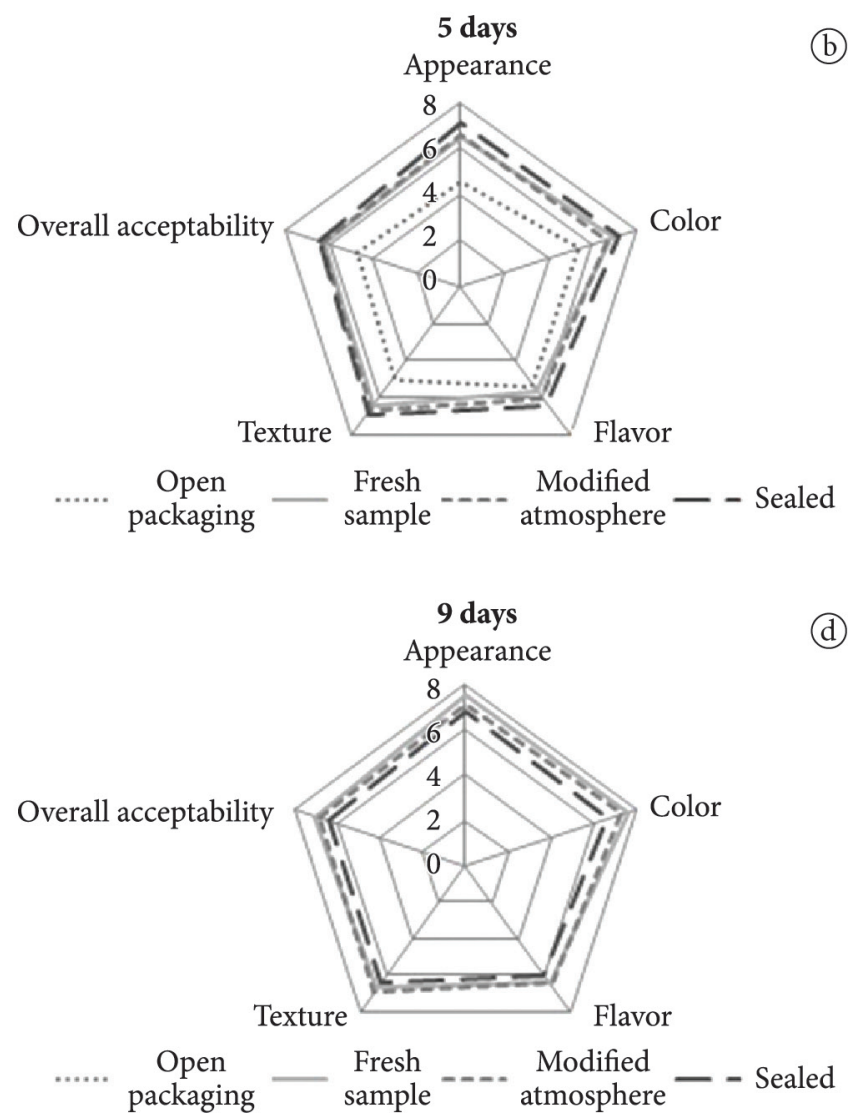

Figure 4: 3 days (a); 5 days (b); 7 (c) days; 9 days (d) of storage of minimally processed radicchio cv., Folha Larga cultivar, packaged and stored under modified atmosphere at $5 \pm 1^{\circ} \mathrm{C}$ for a period of 9 days. ${ }^{\star}$ Different letters indicate significant difference according to Tukey test at $5 \%$ probability. 
under modified atmosphere, but when compared with sealed samples, a significant difference was observed.

After nine days of storage, it was possible to verify a significant difference in color due to chlorophyll degradation of (Figure 4d). There was no difference in the attributes evaluated in the first 9 days of storage, except for the unpackaged samples. The average overall acceptance score of the samples packaged under modified atmosphere on the ninth day of storage was 6.83 (76\% acceptance) using a nine-point hedonic scale in which it corresponds to "slightly liked" and "moderately liked".

On the other hand, the overall acceptance of the samples packaged without modified atmosphere, was $70 \%$, while the unpackaged samples scored $77 \%$ of approval.

\section{Conclusion}

The use of modified atmosphere, combined with cooling and good manufacturing practices, was sufficient to prolong the shelf life of minimally processed radicchio, Folha Larga cultivar, for up to nine days of storage.

The values of molds and yeasts found in the control sample were relatively low. The sanitizing solutions containing sodium hypochlorite (150 mg. $\mathrm{L}^{-1}$ ) provided greater safety to the final product and were more effective than hydrogen peroxide (4\%) in inhibiting the growth of the microorganisms evaluated.

Although the samples packaged under modified atmosphere had higher acceptance scores, the samples in sealed packages had satisfactory results during the nine days of storage.

The use of this technology in industries is viable for longer storage since the degradation process in samples packaged without modified atmosphere initiates after long term storage.

\section{References}

Alzamora, S. E., Tapia, M. S., \& López-Malo, A. (2000). Minimally processed fruits and vegetables: fundamental aspect and applications (pp. 277-286). Maryland: Aspen.

Association of Official Analytical Chemistry - AOAC. (1992). Official methods of analysis of the Association of Official Analytical Chemistry. 11 th ed. Washington. $1015 \mathrm{p}$.

Ahvenainen, R. (1996). New approaches in improving the shelf life of minimally processed fruit and vegetables. Trends In Food Science \& Technology, 7(6), 179-187. http://dx.doi.org/10.1016/09242244(96)10022-4

Babic, I., \& Watada, A. E. (1996). Microbial populations of fresh-cut spinach leaves affected by controlled atmospheres. Postharvest Biology and Technology, 9(2), 187-193. http://dx.doi.org/10.1016/ S0925-5214(96)00047-6

Berbari, S. A. G., Paschoalino, J. E., \& Silveira, N. F. A. (2001). Efeito do cloro na água de lavagem para desinfecção de alface minimamente processada. Ciência e Tecnologia de Alimentos, 21(2), 197-201. http:// dx.doi.org/10.1590/S0101-20612001000200014

Bolin, H. R., \& Huxsoll, C. C. (1991). Effect of preparation procedures and storage parameters on quality retention of saladcut lettuce. Journal Of Food Science, 56(1), 60-62. http://dx.doi. org/10.1111/j.1365-2621.1991.tb07975.x
Brand-Williams, W., Cuvelier, M. E., \& Berset, C. (1995). Use of a free radical method to evaluate antioxidant activity. Lebensmittel - Wissenschaft Und -Technologie, 28(1), 25-30. http:// dx.doi.org/10.1016/S0023-6438(95)80008-5

Brasil. Ministério da Agricultura, Pecuária e Abastecimento. Departamento de Inspeção de Produtos de Origem Animal. (2003). Oficializa os métodos analíticos oficiais para análises microbiológicas para controle de produtos de origem animal e água (Instrução Normativa no 62, de 26 de agosto de 2003). Diário Oficial da República Federativa do Brasil, seção 1, p. 14.

Carazzone, C., Mascherpa, D., Gazzani, G., \& Papetti, A. (2013). Identification of phenolic constituents in red chicory salads (Cichorium Intybus) by high-performance liquid chromatography with diode array detection and electrospray ionizationtandem mass spectrometry. Food Chemistry, 138(2-3), 1062-1071. PMid:23411215. http://dx.doi.org/10.1016/j.foodchem.2012.11.060

Chu, Y.-H., Chao, C.-L., \& Hsu, H.-F. (2000). Flavonoid content of several vegetables and their antioxidant activity. Journal of The Science of Food and Agriculture, 80(5), 561-566. http:// dx.doi.org/10.1002/(SICI)1097-0010(200004)80:5<561::AIDJSFA574>3.0.CO;2-\#

Dalar, A., \& Konczaka, I. (2014). Cichorium Intybus from eastern anatolia: phenolic composition, antioxidant and enzyme inhibitory activities. Industrial Crops and Products, 60, 79-85. http://dx.doi. org/10.1016/j.indcrop.2014.05.043

Engel, V. L. (1991). Estudo da concentracao de clorofila nas folhas e seu espectro de absorcao de luz em função do sombreamento em mudas de quatro especies florestais nativas. Revista Brasileira de Fisiologia Vegetal, 3(1), 39-45.

Gazzani, G., Daglia, M., Papetti, A., \& Gregotti, C. (2000). "In vitro and ex vivo anti- and prooxidant components of Cichorium Intybus. Journal Of Pharmaceutical and Biomedical Analysis, 23(1), 127-133. http://dx.doi.org/10.1016/S0731-7085(00)00282-X

Gorny, J. 2001. A summary of C.A and M.A recommendations for selected fresh-cut. fruits and vegetables. In Optimal controlled atmospheres for horticultural perishables (Postharvest Horticulture Series No. 22A). Davis: University Of California.

Heimler, D., Isolani, L., Vignollini, P., \& Romani, A. (2009). Polyphenol content and antiradical activity of Cichorium Intybus L. from biodynamic and conventional farming. Food Chemistry, 114(3), 765-770. http://dx.doi.org/10.1016/j.foodchem.2008.10.010

Kuskoski, E. M., Asuero, A. G., Troncoso, A. M., Mancini-Filho, J., \& Fett, R. (2005). Aplicacíon de diversos metodos químicos para determinar actividad antioxidante en pulpa de frutos. Ciência e Tecnologia de Alimentos, 25(4), 726-732. http://dx.doi.org/10.1590/ S0101-20612005000400016

Maistro, L. C. (2001). Alface minimamente processada: uma revisão. Revista de Nutrição, 14(3), 219-224. http://dx.doi.org/10.1590/ S1415-52732001000300008

Manolopoulou, H., Lambrinos, G. R., Chatzis, E., Xanthopoulos, G., \& Aravantinos, E. (2010). Effect of temperature and modified atmosphere packaging on storage quality of fresh-cut romaine lettuce. Journal of Food Quality, 33(Suppl. s1), 317-336. http:// dx.doi.org/10.1111/j.1745-4557.2010.00321.x

Meilgaard, M., Civille, G. V., \& Carr, B. T. (2007). Sensory evaluation techniques. 4 th ed. Boca Raton: CRC Press.

Minolta, K. (1998). Comunicação precisa da cor: controle de qualidade, da percepção à instrumentação. Osaka: Konika Minolta Sensing Inc. p. 1-59. 
Morales, P., Ferreira, I. C. F. R., Carvalho, A. M., Sánchez-Mata, M. C., Cámara, M., Fernandez-Ruiz, V., Pardo-De-Santayana, M., \& Tardío, J. (2014). Mediterraneannon-cultivated vegetables as dietary sources of compounds with antioxidantand biological activity. LWT - Food Science and Technology, 55(1), 389-396. http://dx.doi. org/10.1016/j.lwt.2013.08.017

Nandagopal, N., \& Kumari, B. D. R. (2007). Phytochemical and antibacterial studiesof chicory (Cichorium Intybus L.): a multipurpose medicinal plant. Advances In Biology Research, 1(12), 17-21.

Peters, A. M., Haagsma, N., Gensch, K. H., \& Vanamerongen, A. (1996). Production and characterization of polyclonal antibodies against the bitter sesquiterpenelactones of chicory (Cichorium Intybus L.). Journal of Agricultural and Food Chemistry, 44(11), 3611-3615. http://dx.doi.org/10.1021/jf950812s

Pirovani, M. E. (1998). Quality of minimally processed lettuce as influenced by packaging and chemical treatment. Journal of Food Quality, 21(6), 475-484. http://dx.doi.org/10.1111/j.1745-4557.1998. tb00537.x

Rinaldi, M. M., Benedetti, B. C., Sarantópoulos, C. I. G. L., \& Moretti, C. L. (2009). Estabilidade de repolho minimamente processado sob diferentes sistemas de embalagem. Ciência e Tecnologia de Alimentos, 29(2), 310-315. http://dx.doi.org/10.1590/S010120612009000200012

Robertson, T. R. (2003). Use of modified-atmosphere packaging. In B. Caballero, L. Trugo \& PM Finglas (Eds.), Encyclopedia of Food
Sciences and Nutrition (2nd ed.,pp. 1186-1190). San Diego: Academic Press. http://dx.doi.org/10.1016/B0-12-227055-X/00217-0

Roversi, R. M., \& Masson, M. L. (2004). Qualidade da alface crespa minimamente processada acondicionada em atmosfera modificada. Ciência e Agrotecnologia, 28(4), 823-830.

Silva, J. M., Spoto, M. H. F., Ongarelli, M. G., Aguila, J. S. D., Sasaki, F. F., \& Kluge, R. A. (2007). Métodos de determinação de clorofila em alface e cebolinha minimamente processadas. Revista Iberoamericana Tecnología Postcosecha, 8(2), 53-59.

Statsoft. (2005). Statistica: data analysis software system. Version 10.0. Tulsa.

Street, R. A., Sidana, J., \& Prinsloo, G. (2013). Cichorium Intybus: traditional uses, phy-tochemistry, pharmacology and toxicology. Evidence-Based Complementary and Alternative Medicine, 2013, 1-13. PMid:24379887 PMCid:PMC3860133. http://dx.doi. org/10.1155/2013/579319

Streit, N. M., Canterle, L. P., Canto, M. W., \& Hecktheuer, L. H. H. (2005). As clorofilas. Ciência Rural, 35(3), 748-755. http://dx.doi. org/10.1590/S0103-84782005000300043

Walley, P. G., \& Buchanan-Wollaston, V. (2011). Health-promoting properties of fruits \& vegetables. In L. Terry (Ed.), Head of plant science laboratory. Cranfield: Cranfield University.

Witham, F. H., Blaydes, D. F., \& Devlin, R. M. (1971). Experiments in plant physiology. New York: Van Nostrand Reinhold Co. 